\title{
Crowdfunding: The Current State Of Research
}

Ricarda B. Bouncken, University of Bayreuth, Germany

Malvine Komorek, Lappeenranta University of Technology, Finland

Sascha Kraus, University of Liechtenstein, Liechtenstein

\begin{abstract}
Crowdfunding represents an alternative way of funding compared to traditional borrowing. As a principle, crowdfunding is open to everyone - private persons as well as economic actors. A group of people, the crowd, financially contributes small amounts to projects, products or ideas. These projects, products or ideas are owned by fundraisers (e.g. entrepreneurs or private persons), seeking for money in order to get their project realized. Fundraisers search for investors directly or via a specific digital platform, referred to as intermediaries. Crowdfunding represents a recent web 2.0 based phenomenon gaining more and more scientific attention. Therefore, this article seeks to give an overview on the current state of scientific knowledge on the topic, summarizing core definitions as well as characteristics.
\end{abstract}

Keywords: Crowdfunding; Literature Review; Status Quo

\section{INTRODUCTION}

rowdfunding, as the contribution of a financial amount to projects, products or business ideas by a number of investors (Wenzlaff et al., 2012), has recently emerged as an alternative possibility for individuals to receive funding (Agrawal et al., 2013; Kleeman et al., 2008; Unterberg, 2010). The concept of mobilizing funding in small pieces is old and can be found in every incorporation (Fiedler and Horsch, 2014; Harrisson, 2013; Zademach and Baumeister, 2013). Contrary to typical financial investments, crowdfunding is fundamentally open to everyone (Blohm et al., 2013; Wenzlaff et al., 2012). Originally, the concept gained prominence with the financing of artists or creative projects and then spread across more sectors (Bradford, 2012; Meinshausen et al., 2012). As statistics emphasize, crowdfunding is rapidly growing. US\$ 2.7 billion were contributed with over a million different crowdfunding incentives in 2012. By 2013, this amount increased over $51 \%$ to US\$ 5.1 billion (Massolution, 2013). Therefore, it represents a highly discussed topic on a global basis in younger media (e.g. Spiegel Online, 2014) but also scientific articles since 2010 (Moritz and Block, 2014).

Crowdfunding is a web 2.0 based phenomenon (Leimeister, 2012). Crucial factor for success of the concept is the digitalization of society with growing presence of the internet. The number of internet users increased up to almost $570 \%$ between 2000 and 2012 (Internet World Stats, 2013). Today, markets are growingly saturated with digital equipments and accounts (Stalder, 2009). People are able to communicate, access and provide information constantly (Castells, 2009; Wolf et al., 2012). As a recent development, people are willing to also contribute and give, fostering the rapid development of crowdfunding since about five years (Aaker and Akutsu, 2009).

This paper seeks to contribute to scientific research on crowdfunding, giving an overview on fundamental findings concerning crowdfunding. The content of this paper is based on a comprehensive literature review of scientific publications on crowfunding from the period 2000 to 2014. A database search using the University of Leicester Online Library, Web of Science (Thomson Reuters), and EBSCO (EconLit, Business Source Premier, Academic Search Premier, Science Direct, Emerald Management Xtra, and the Web of Science (Social Sciences Citation Index)) resulted in usable texts. In August 2014, a search request on Web of Science (Thomson Reuters) with "crowdfunding" as well as "crowd funding" in title search, added up to usable of peer-group reviewed studies. The selection and identification of relevant publications was conducted with certain key words (including 
crowdfunding, crowd funding and crowdfinancing) in their titles and/or abstracts. The systematic literature review was conducted following the approach by Tranfield et al. (2003), the studies were analyzed and classified due to their validity and their content as a contribution to the scientific discipline.

This article focuses on key aspects of scientific research on crowdfunding. It is structured as follows: Subsequent to the introduction, existing definitions will be presented. Additional focal areas of research like the economic basis of crowdfunding (two-sided-market), crowdfunding models, direct vs. indirect crowdfunding as well as the different actors involved in the crowdfunding process will be presented. An outlook on future research and a conclusion will finalize this work.

\section{REVIEW}

\section{Definitions}

Crowdfunding represents one dimension of the phenomenon of crowdsourcing besides crowdvoting and crowdcreation (e.g. Leimeister, 2012; Leimeister and Zogaj, 2013; Richter et al., 2014). The term crowdsourcing is composed of "crowd" and "outsourcing", pointing to the meaning to outsource specific functions to a group of external persons (Kleeman et al., 2008). The concept is based on the idea of "wisdom of a crowd" (Surowiecki, 2004). It represents an approach being in a juvenile state of scientific research (Howe, 2008). Jeff Howe (2006a; 2006 ; 2008) was the first to define crowdsourcing in an online article in 2006. Up to today, his definition remains the most prominent scientific one, which we therefore follow (Brabham, 2009; Starbird, 2012).

The act of taking a job traditionally performed by a designated agent (usually an employee) and outsourcing it to an undefined, generally large of people in the form of an open call. (Howe, 2006b, p. 1)

Besides crowdsourcing (Howe, 2008), crowdfunding is closely connected to micro lending (Vitale, 2013). Micro lending refers to the the idea of funding of individuals, who do not have access to conventional financing from credit institutions (Armendariz and Morduch, 2010).

As for crowdsourcing, various definitions of crowdfunding exist of which none did receive overall scientific acceptance (e.g. Tomczak and Brem, 2013). Therefore, prominent existing definitions will be presented in the following table: 
Table 1: Definitions Of Crowdfunding

\begin{tabular}{|c|c|}
\hline Authors & Definition \\
\hline $\begin{array}{l}\text { Belleflamme et al., } \\
2010, \text { p. } 5\end{array}$ & $\begin{array}{l}\text { Crowdfunding involves an open call, essentially through the Internet, for the provision of } \\
\text { financial resources either in form of donation or in exchange for some form of reward and/or } \\
\text { voting rights. }\end{array}$ \\
\hline $\begin{array}{l}\text { Fiedler and Horsch, } \\
\text { 2014, p. } 92\end{array}$ & $\begin{array}{l}\text { Crowdfunding comprises forms of capital supply, with which capital seeking companies } \\
\text { publicly present themselves on specific internet based platforms to a big group of potential } \\
\text { capital providers based on their innovative business idea and offer this group the opportunity } \\
\text { to engage themselves with the allocation of funding (translated from German). }\end{array}$ \\
\hline $\begin{array}{l}\text { Hemer et al., } \\
2011, \text { p } 5\end{array}$ & $\begin{array}{l}\text { Crowdfunding is a form of project and innovation funding with micropayments (translated } \\
\text { from German). }\end{array}$ \\
\hline $\begin{array}{l}\text { Lambert and Schwienbacher, } \\
2010 \text {, p. } 4\end{array}$ & $\begin{array}{l}\text { An open call, essentially through the Internet, for the provision of financial resources either in } \\
\text { form of donation or in exchange for some form of reward and/or voting rights in order to } \\
\text { support initiatives for specific purposes. }\end{array}$ \\
\hline $\begin{array}{l}\text { Tomczak and Brem, } \\
2013 \text {, p. } 338\end{array}$ & $\begin{array}{l}\text { The act of taking a loan/funding traditionally performed by a designated agent and } \\
\text { outsourcing it to an undefined, generally large group of people in the form of an open call. }\end{array}$ \\
\hline $\begin{array}{l}\text { Voorbraak, } \\
\text { 2011, p. } 1\end{array}$ & $\begin{array}{l}\text { The process of one party requesting and receiving money and other resources from many } \\
\text { individuals for financing a project, in exchange for monetary or non-monetary return on } \\
\text { investment. }\end{array}$ \\
\hline $\begin{array}{l}\text { Wenzlaff et al., } \\
\text { 2012, n.p. }\end{array}$ & $\begin{array}{l}\text { Crowdfunding is a type of fundraising for creative projects, but also for companies. Most } \\
\text { important aspect is, that crowdfunding is open, uses the methods of web } 2.0 \text { for } \\
\text { communication and has usually a type of material or immaterial rewarding (translated from } \\
\text { German). }\end{array}$ \\
\hline
\end{tabular}

Bottom line of all definitions from numerous authors is, that crowdfunding focuses on raising financial funding from the public, represented by a group of people, by using specific internet-based platforms (e.g. Mazzola and Distefano, 2010; Ribiere and Tuggle, 2010; Yang et al., 2008).

\section{Crowdfunding As A Two-Sided Market}

Crowdfunding is regarded as a typical two-sided market as it "ties together two distinct groups of users in a network" (Eisenmann et al., 2006, p. 2). Two-sided networks are characterized by a subsidy-side and a money-side. The subsidy-side is the group of investors contributing to the money-side, the fundraiser, while paying no fees to the platform (e.g. Osterwalder and Pigneur, 2010). Intermediaries charge different amounts to fundraisers while investors are not charged separate fees (e.g. Indiegogo, 2014; Kickstarter, 2014).

\section{Crowdfunding Models}

The dimensions of crowdfunding differentiate in terms of the allocation of resources and the reflux to investors (e.g. Moritz and Block, 2014; Zhang, 2013). In general, participants in the crowd can be rewarded in different ways: material (Vukovic et al., 2009) or immaterial via social acknowledgement (Kazai, 2011). Materially, the compensation can be monetarily as the project initiators agree to refund the paid amount directly or indirectly with products or services (Pelzer et al., 2012). Overall four models in terms of financing do exist (e.g. Beck, 2012; Giudici et al., 2012; Leimeister, 2012). Scholars divide crowdfunding into a donations, reward, lending and equity model.

The donations model refers to a classic fundraising objective with the difference that the donations are made via web 2.0 and, in most cases, a specific intermediary. Donators receive no material but immaterial, social rewarding in return for their contributions - e.g. public acknowledgements by the fundraisers (Leimeister and Zogaj, 2013). For the realization of creative projects, the donations model is commonly applied. It is also regarded as a rising opportunity for public institutions, such as libraries, to be financially funded by the crowd (McKinley, 2012). The only immaterial rewarding represents an option for investors to take part in "real-world problems" (Wiggins and Crowston, 2011, p. 1) with their engagement in the crowd.

The reward model includes both, material and immaterial rewarding. For crowdsponsoring investors are solely rewarded via acknowledgements (intersection to the donations model) as their name might appear in the 
funded project (Belleflamme et al., 2013; Kortleben and Vollmar, 2012). In pre-selling or also pre-ordering, rewarding is materially based as investors receive the financed project or product before publication or market entrance (Hemer et al., 2011; Röthler and Wenzlaff, 2011).

Small loans are given in the lending model. Investors receive a fixed interest rate in this case. These kinds of contracts can either be made between private persons when a private investors finances a private fundraiser (Peerto-Peer-Lending) (Hemer et al., 2011; Kaltenbeck, 2011; Kortleben and Vollmar, 2012), or from private persons to companies (Barasinka and Schäfer, 2010; Mach et al., 2013).

The equity model comprises a fundraising via selling shares of the fundraised company to the crowd. This is especially in the german-speeking area often described as crowdinvesting (e.g. Leimeister and Zogaj, 2013; Hornuf and Klöhn, 2013) or "investment crowdfunding" (Barnett, 2013, p. 1), when start-ups and entrepreneurs receive money from the crowd and bridge early stage gaps in funding (Mollick, 2013). Investors receive a profit sharing as a material reward (Beck, 2012; Brem and Wassong, 2014). This model has received highest scientific attention in the past (e.g. Moritz and Block, 2014).

\section{Direct vs. Indirect Crowdfunding}

Crowdfunding can be divided into direct and indirect crowdfunding. Direct crowdfunding refers to a direct funding appeal from fundraisers to the crowd, e.g. on the website of the company. Indirect crowdfunding involves an intermediary in the crowdfunding process as the appeal is announced via a specific platform (Belleflamme et al., 2010; Burkett, 2011; Lambert and Schwienbacher, 2010). What makes direct crowdfunding less advantageous for unknown fundraisers (e.g. entrepreneurs) is the fact, that they would directly have to be able to address a large number of people via their own website. No required minimum number of participants in the crowd could be found in the current state of literature on the topic. However, Howe (2006a; 2006b; 2008) claimed a size of 5.000 participants in a crowd to be decisive for a successful crowdfunding campaign. This number seems to be calculated too high since famous crowdfunding platforms state an maximum average of 500 to 600 participants (Crowdcube, 2014; Kickstarter, 2014; Seedmatch, 2014). Still, most crowdfunding is conducted in reality indirectly via an intermediary which is emphasized by a growing number of crowdfunding platforms (e.g. Moritz and Block, 2014).

\section{Actors Involved In Crowdfunding}

Three different kinds of actors are involved in typical crowdfunding: intermediaries, fundraisers and investors (Tomczak and Brem, 2013).

\section{Intermediaries}

First, the intermediary, as the internet-based platform, takes an important role in connecting and matching fundraisers and investors (Zvilichovsky et al., 2013). Intermediaries ensure standardized crowdfunding processes for the investors and serve as a platform for communication, information and execution at the same time. Close communication between fundraiser and investor is important in order to receive a successful funding of the incentive (Brabham, 2009; Estellés-Arolas and González-Ladrón-de-Guevara, 2012; Howe, 2006b). Intermediaries follow different investment models (Barnett, 2013). All-or-nothing implies that the fundraiser only receives the amount if a previously defined threshold of investments is reached whereas fundraisers receive all investments in the keep-whatyou-get model (e.g. Mahlstede, 2012; Moritz and Block, 2014). Intermediaries vary in their focus. Specific platforms for creative projects (indiegogo or RocketHub), organizational and corporate projects (Crowdfunder) or fundraising (Crowdrise, 2aid, Betterplace) (Grimme Institut, 2012; Wheat et al., 2013) do exist. Main fields of application of crowdfunding platforms are acquisition of contents, design \& improvement, sales \& marketing as well as research \& development (Kaganer et al., 2013). In addition, platforms of social networking are of relevance since crowdfunding projects are communicated on them. Facebook or twitter serve can serve as a promoter of crowdfunding incentives (Belleflamme et al., 2011). The social support is of specific importance for fundraising (Wheat et al., 2013). 


\section{Fundraisers}

Second, fundraisers comprise the individuals, seeking for funding. Crowdfunding provides them access to a market on one hand while raising money on the other hand (Burkett, 2011). As crowdfunding is fundamentally open, the typology of fundraisers can vary from companies (Burger-Helmchen and Penin, 2010), industries (Grier, 2011), institutions (Howe, 2006a) or non-profit organizations (Brabham, 2009). Currently, scientific research has focused primarily on companies as fundraisers (Moritz and Block, 2014). Requirements to be fulfilled by the fundraiser in order to initate a crowdfunding project are minor (Estellés-Arolas and González-Ladrón-de-Guevara, 2012) as the self-marketing of the fundraisers idea is referred to as the most important requirement (Pelzer et al., 2012).

To start a crowdfunding project, fundraisers have to apply to the platform with detailed information on the project or to the company (e.g. Belleflamme et al., 2011). The platform then decides on publishing the project or declining it.

Scholars identified different motivations for participating in crowdfunding. The primary focus of fundraisers is to receive funding whereas raising awareness as well as feedback on the project, product or business idea is less important. Kleeman et al. (2008) state a growing importance of the feedback aspect as customers gain more and more influence on the value added process. Crowdinvesting for start-ups offers entrepreneurs the possibility to bridge the early-stage-gap in which conservative funding is not possible (Hemer et al., 2011). Furthermore, access to the knowledge of the crowd is provided while duties towards investors remain minor (Surowiecki, 2004). At the same time, the base of potential customers is increased which, empirically confirmed, leads to higher sales. Market potential can be more efficiently exploited (Belleflamme et al., 2010).

The characteristics of the fundraisers influences the chance for a project to be successfully funded (Moritz and Block, 2014). Investors contribute to projects they want so see realized (Belleflamme et al., 2013). Therefore, non-profit organizations or socially focused companies are more likely to be supported by investors than others (Belleflamme et al., 2010). An additional success factor is the period of funding and the amount. Usually, crowdfunding incentives are limited to a certain period between 30 and 90 days (Mahlstede, 2012). The proximity of a realization of the crowdfunding incentive depends on the time period of the incentive as well as the requested amount of funding. The longer the time period and the higher the requested amount, the lower will be the proximity of the crowdfunding incentive to receive full funding.

Investors

Third and last, investors represent the crowd, who "[...] decide to financially support these projects, bearing a risk and expecting a certain payoff" (Ordanini et al., 2011, p. 5). These investors are in terms of indirect crowdfunding registered users with access to the project information (e.g. Baba et al., 2014). In case of interest, investors contribute a fixed amount via a bank or micopayment provider. The crowd, as a group of recipients of the task, usually stays anonymous regarding crowd and the fundraiser(s) (Poetz and Schreier, 2009; Wexler, 2011). Investors are intelligent, qualified persons (Howe, 2008). A necessary qualification in order to take part in crowdfunding as an investor is not determined: users and consumers (Kleeman et al., 2008), amateurs (Schenk and Guittard, 2011) or individuals, seeking for commitment (Grier, 2011; Heer and Bostok, 2010) are regarded as members of the crowd. The crowdwork can either be tournament-based or collaboration-based (Leimeister, 2012). The primary focus on the crowd needs to be the collaborative funding of the incentive instead of aiming to individually work on a solution (Howe, 2006a). For crowdsourcing in general, these social effects are comprised by terms such as "crowd wisdom" (Brabham, 2009, p. 248; see also Leimeister, 2012, p. 388) or "collaborative knowledge" (Pelzer et al., 2012, p. 20).

Social reputation and intrinsic motives represent the main impetus for investors to participate in crowdfunding, extrinsic motives such as financial rewarding are less relevant (e.g. Lambert and Schwienbacher, 2010; Richter et al., 2014). Therefore, the identification with the incentive, project or company, represents a crucial factor (e.g. Eickhoff and De Vries, 2011). In most cases, investors are particularly motivated to fund when they regard the quality of the incentive as high (e.g. Mollick, 2013). Currently, the IT-developer Chris Roberts is seeking 
for contributions for his new computer game "star citizen". As an appetizer, potential investors can log on a virtual platform to receive first insights in the computer game (Spiegel Online, 2014). Social networks influence the motivation of investors in addition (Lawton and Marom, 2010). When the number of investors in an incentive rises, other potential investors react with lower investments since they expect the incentive to be fully funded. As a result, the number of investor freezes or decreases and motivates the investors to finally contribute as they want to ensure the realization of the incentive (e.g. Smith et al., 2013).

\section{CONCLUSIONS}

The research field of crowdfunding is in a young state of scientific research. Quantitative studies are minor. Former studies focus on crowdfunding models as well as on the role of the actors in the process: intermediaries, fundraisers and investors. Previously, studies focused on companies as fundraisers (e.g. Brem and Wassong, 2014; Mollick, 2013; Tomczak and Brem, 2013). In terms of theoretical foundations, no consensus on definitions, dimensions or characteristics does exist. There is no detailed literature analysis, giving a generic overview on the state of research on crowdfunding. Three literature reviews could be identified. Bachmann et al. (2011) focus on peer-to-peer lending only while Feller et al. (2013) analyze crowdfunding quantitatively in terms of dimensions. Moritz and Block (2014) focus on literature on early-stage funding primarily.

As the numbers of intermediaries are rising rapidly, the crowdfunding movement is continuously developing (Mahlstede, 2012). As a result, scientific contributions are continuously challenged by new developments. Constantly new research is needed. Currently, crowdfunding is primarily regarded from a positive perspective as an alternative opportunity to receive funding. Limits and challenges of the approach received less scientific attention in the past and should be illuminated in the future.

\section{ACKNOWLEDGEMENTS}

This publication was funded by the German Research Foundation (DFG) and the University of Bayreuth in the funding programme Open Access Publishing.

\section{AUTHOR INFORMATION}

Ricarda Bouncken is Chair Professor of Strategy and Organization at the University of Bayreuth, Germany. Her research centers on diversity, innovation, and collaboration.

Email: bouncken@uni-bayreuth.de (Corresponding author)

Malvine Komorek is a doctoral student a Lappeenranta University of Technology, Finland. Before that, she pursued a Bachelor's degree in Applied Geography and a Master's in Economic Geography at RWTH Aachen University, Germany.

Email: $\underline{\text { m@komorek.eu }}$

Sascha Kraus is a Professor for Entrepreneurship at the University of Liechtenstein and a Visiting Professor at the University of St. Gallen, Switzerland and Utrecht University, The Netherlands. He is also an Adjunct Professor at Lappeenranta University of Technology, Finland.

Email: $\underline{\text { sascha.kraus@unisg.ch }}$

\section{REFERENCES}

Aaker, J. and Akutsu, T. (2009) 'Why do People Give? The Role of Identity in Giving', Journal of Consumer Psychology, Vol. 19, No. n.I., pp.267-270.

Agrawal, A., Catalini, C. and Goldfarb, A. (2013) The Simple Economics of Crowdfunding, Innovation Policy and the Economy. Chicago: University Press.

Armendariz, B. and Morduch, J. (2010) The Economimcs of Microfinance, Cambridge, MIT Press.

Baba, Y., Kashima, H., Kinoshita, K., Yamaguchi, G. and Akiyoshi, Y. (2014) 'Leveraging non-expert crowdsourcing workers for improper task detection in crowdsourcing marketplaces', Expert Systems with Applications, Vol. 41, 
No. 6, pp.2678-2687.

Bachmann, A., Becker, A., Buerckner, D., Hilker, M., Kock, F., Lehmann, M. and Tiburtus, P. (2011) 'Online Peer-toPeer-Lending - A Literature Review', Journal of Internet Banking and Commerce, Vol. 16, No. 2, pp.n.p.

Barasinka, N. and Schäfer, D. (2010) 'Does Gender Affect Funding Success at the Peer-to-Peer Credit Markets? Evidence from the largest German Lending Platform', DIW Discussion Paper, Vol. 2010, No. 1094.

Barnett, C. (2013) Top 10 Crowdfuning Sites for Fundraising. New York: Forbes.

Beck, R. (2012) Crowdinvesting: Die Investition der Vielen, Düsseldorf, CreateSpace Independent Publishing Platform.

Belleflamme, P., Lambert, T. and Schwienbacher, A. (2010) 'Crowdfunding: An Industrial Organization Perspective', SSRN Working Paper, Vol. 2151179, No.

Belleflamme, P., Lambert, T. and Schwienbacher, A. (2011) 'Crowdfunding: tapping the right Crowd', ECORE Discussion Paper, Vol. 2011, No. 32, pp.1-37.

Belleflamme, P., Lambert, T. and Schwienbacher, A. (2013) 'Individual crowdfunding practices', Venture Capital, Vol. 15, No. 4, pp.313-333.

Blohm, I., Leimeister, J.-M., Wenzlaff, K. and Gebert, M. (2013) Crowdfunding Studie 2013/2014, Berlin, epubli.

Brabham, D.C. (2009) 'Crowdsourcing the Public Participation Process for Planning Projects', Planning Theory, Vol. 8, No. 3, pp.242-262.

Bradford, C.S. (2012) 'Crowdfunding and the Federal Securities Law', Columbia Business Law Review, Vol. 2012, No. 1, pp.1-150.

Brem, A. and Wassong, N. (2014) 'Wer investiert warum? Eine Analyse von Investmententscheidungen bei Crowdfunding-Projekten', Zeitschrift für KMU und Entrepreneurship, Vol. 2014, No. 1, pp.31-56.

Burger-Helmchen, T. and Penin, J. (2010) 'The limits of Crowdsourcing in inventive activities: What do transaction cost theory and evolutionary theories of the firm teach us', Workshop on Open Source Innovation Strasbourg, Vol. 2010, No. none, pp.1-26.

Burkett, E. (2011) 'A Crowdfunding Exemption? Online Investment Crowdfunding and U.S. Securities Regulation', Transactions: The Tennessee Journal of Business Law, Vol. 1, No. n.I., pp.63-106.

Castells, M. (2009) Communication Power, New York, Oxford University Press.

Crowdcube (2014) Infographic, http://www.crowdcube.com/infographic, accessed on 14.08.2014.

Eickhoff, C. and De Vries, A.P. (2011) 'How Crowdsourcable is your Task?', Workshop on Crowdsourcing for Search and Data Mining (CSDM), Vol. 2011, No. none, pp.1-4.

Eisenmann, T., Parker, G. and Van Alstyne, M.W. (2006) 'Strategies of Two-Sided Markets', Harvard Business Review, Vol. 84, No. 10, pp.1-11.

Estellés-Arolas, E. and González-Ladrón-de-Guevara, F. (2012) 'Towards an integrated crowdsourcing definition', Journal of Information Science, Vol. 38, No. 2, pp.189-200.

Feller, J., Gleasure, R. and Treacy, S. (2013) From the Wisdom to the Wealth of Crowds: A Metratriangulation of Crowdfunding Research, TOTO Research Project 2013.01.V2.

Fiedler, S. and Horsch, A. (2014) 'Crowdinvesting als Finanzierungsalternative', Zeitschrift für KMU und Entrepreneurship, Vol. 1, No. 2014, pp.91-98.

Giudici, G., Nava, R., Rossi Lamastra, C. and Verecondo, C. (2012) Crowdfunding: The New Frontier for Financing Entrepreneurship?, SSRN Working Paper 2157429.

Grier, D.A. (2011) 'Not for All Markets', Computer, Vol. 44, No. 5, pp.6-8.

Grimme Institut (2012) Im Blickpunkt: Crowdsourcing, Marl/Düsseldorf, Grimme Institut/ Medienkompetenz NRW.

Harrisson, R. (2013) 'Crowdfunding and the revitalisation of the early stage risk capital market: catalyst or chimera?', Venture Capital: An International Journal of Entrepreneurial Finance, Vol. 15, No. 4, pp.283-287.

Heer, J. and Bostok, M. (2010) Crowdsourcing graphical perception: using mechanical turk to assess visualization design. Paper presented at Proceedings of the 28th international conference on Human factors in computing systems, Atlanta.

Hemer, J., Schneider, U., Dornbusch, F. and Frey, S. (2011) Crowdfunding und andere Formen informeller Mikrofinanzierung in der Projekt- und Innovationsfinanzierung, Karlsruhe, Fraunhofer ISI.

Hornuf, L. and Klöhn, L. (2013) 'Crowdinvesting und Portfoliodiversifizierung - Eine rechtsökonomische Analyse', Venture Capital Magazin, Vol. 2013, No. 2, pp.34-35.

Howe, J. (2006b) Crowdsourcing: A Definition: Crowdsourcing.

Howe, J. (2008) Crowdsourcing: Why the Power of the Crowd is driving the Future of Business, New York, Crown Business.

Howe, J. (2006a) 'The Rise of Crowdsourcing', Wired Magazine, Vol. 14, No. 6, pp.1-5.

Indiegogo (2014) Über uns, http://www.indiegogo.com/about/our-story, accessed on 14.08.2014.

Internet World Stats (2013) World Internet Usage and Population Statistics, http://www.internetworldstats.com/stats.htm, accessed on 10.08.2014. 
Kaganer, E., Carmel, E., Hirschheim, R. and Olsen, T. (2013) 'Managing the Human Cloud', MIT Sloan Management Review, Vol. 54, No. 2, pp.23-32.

Kaltenbeck, J. (2011) Crowdfunding und Social Payments im Anwendungskontext von Open Educational Resources, Berlin, epubli.

Kazai, G. (2011) 'In Search of Quality in Crowdsourcing for Search Engine Evaluation', Computer Science, Vol. 2011 , No. 5511, pp.165-176.

Kickstarter (2014) What is Kickstarter, http://www.kickstarter.com/help/faq/creator+questions?ref=faq_subcategory\#PaymUs, accessed on 14.08.2014.

Kleeman, F., Voß, G.G. and Rieder, K. (2008) 'Un(der)paid Innovators: The Commercial Utilization of Consumer Work through Crowdsourcing', Science, Technology and Innovation Studies, Vol. 4, No. 1, pp.5-26.

Kortleben, H. and Vollmar, B. (2012) 'Crowdinvesting - eine Alternative in der Gründungsfinanzierung?', Forschungspapiere PFH, Vol. 2012, No. 06, pp.n.p.

Lambert, T. and Schwienbacher, A. (2010) An Empirical Analysis of Crowdfunding, Louvain-la-Neuvwe, Louvain School of Management, Catholic University of Louvain.

Lawton, K. and Marom, D. (2010) The Crowdfunding Revolution: Social Networking meets Venture Financing, n.p., thecrowdfundingrevolution.com.

Leimeister, J.M. (2012) 'Crowdsourcing: Crowdfunding, Crowdvoting, Crowdcreation', Zeitschrift für Controlling und Management, Vol. 2012, No. 56, pp.388-392.

Leimeister, J.M. and Zogaj, S. (2013) 'Neue Arbeitsorganisation durch Crowdsourcing', Hans-Böckler-Stiftung Arbeitspapier Arbeit und Soziales, Vol. 2013, No. 287.

Mach, T.L., Carter, C.M. and Slattery, C. (2013) Peer-to-peer lending to small businesses. Paper presented at Federal Reserve System Community Development Research Conference.

Mahlstede, S. (2012) The power of the crowd, Crowdfunding Studienreihe. Stuttgart: Institut für Kommunikation in sozialen Medien.

Massolution (2013) 2013CF - The Crowdfunding Industry Report. New York: Massolution.

Mazzola, D. and Distefano, A. (2010) Crowdsourcing and participation process for problem solving: the case of BP, Naples, VII Conference of the Italian Chapter of AIS, Information technology and Innovation trend in Organization.

McKinley, D. (2012) Practical management strategies for Crowdsourcing in libraries, archives and museums, http://www.digitalglam.org/wp-content/uploads/2013/03/McKinley-2012-Crowdsourcing-managementstrategies.pdf, accessed on 14.08.2014.

Meinshausen, S., Schiereck, D. and Stimeier, S. (2012) 'Crowdfunding als Finanzierungsalternative - Innovative Ansätze in der Unternehmensfinanzierung', WiSt, Vol. 41, No. 11, pp.583-588.

Mollick, E. (2013) 'The dynamics of crowdfunding: An exploratory study', Journal of Business Venturing, Vol. 29 , No. 2014, pp.1-16.

Moritz, A. and Block, J. (2014) 'Crowdfunding und Crowdinvesting: State of the Art der wirtschaftswissenschaftlichen Literatur', ZfKE, Vol. 62, No. 1, pp.57-90.

Ordanini, A., Miceli, M., Pizzetti, M. and Parasuraman, A. (2011) 'Crowd-Funding: Transforming Customers into Investors through Innovative Service Platforms', Journal of Service Management, Vol. 22, No. 4, pp.443-470.

Osterwalder, A. and Pigneur, Y. (2010) Business Model Generation: A Handbook for Visionaries, Game Changers, and Challengers, Hoboken, NJ, Wiley.

Pelzer, C., Wenzlaff, K. and Eisfeld-Reschke, J. (2012) Crowdsourcing-Report 2012 - Neue digitale Arbeitswelten. Berlin: DCV.

Poetz, M.K. and Schreier, M. (2009) 'The Value of Crowdsourcing: Can Users Really Compete with Professionals in Generating New Product Ideas?', Journal of Product Innovation Management, Vol. 29, No. 2, pp.245-256.

Ribiere, V.M. and Tuggle, F.D. (2010) 'Fostering innovation with KM 2.0', VINE, Vol. 40, No. 1, pp.90-101.

Richter, C., Seidler-de Alwis, R. and Jötten, M. (2014) 'Crowdsourcing als Chance für mittelständische Unternehmen', Zeitschrift für KMU und Entrepreneurship, Vol. 1, No. 2014, pp.1-30.

Röthler, D. and Wenzlaff, K. (2011) 'Crowdfunding Schemes in Europe', EENC Report, Vol. 2011, No. 09, pp.n.p.

Schenk, E. and Guittard, C. (2011) What can be Outsourced to the Crowd, and Why?

Seedmatch (2014) Seedfacts, https://www.seedmatch.de/, accessed on 14.08.2014.

Smith, D., Manesh, M.M.G. and Alshaikh, A.A. (2013) 'How Can Entrepreneurs Motivate Crowdsourcing Participants?', Technology Innovation Management Review, Vol. 2013, No. 1, pp.23-30.

Spiegel Online (2014) Netzwelt-Ticker: Star Citizen, Browser-Datenschutz, Musik-Millionen, http://www.spiegel.de/netzwelt/web/wing-commander-nachfolger-star-citizen-finanziert-ueber-crowdfunding-a860675.html, accessed on 15.08.2014.

Stalder, F. (2009) Neun Thesen zur Remix-Kultur. Zürich: Zürcher Hochschule der Künste. 
Starbird, K. (2012) What" Crowdsourcing" Obscures: Exposing the Dynamics of Connected Crowd Work during Disaster. Surowiecki, J. (2004) The wisdom of crowds: Why the many are smarter than the few and how collective wisdom shapes business, economies, societies, and nations, New York, Doubleday.

Tomczak, A. and Brem, A. (2013) 'A conceptualized investment model of crowdfunding', Venture Capital: An International Journal of Entrepreneurial Finance, Vol. 15, No. 4, pp.335-359.

Tranfield, D., Denyer, D. and Smart, P. (2003) 'Towards a Methodology for Developing Evidence-Informed Management Knowledge by Means of Systematic Review', British Journal of Management, Vol. 14, No. 3, pp.207-222.

Unterberg, U. (2010) Crowdsourcing, In Michelis, D. and Schildhauer, T. (eds.), Social Media Handbuch: Theorien, Methoden, Modelle. Baden-Baden: Nomos Verlag, 121-135.

Vitale, M. (2013) Crowdfunding: Recent International Developments and Analysis of Its Compatibility with Australia's Existing Regulatory Framework, http://ssrn.com/abstract=2324573, accessed on 21.03.2014.

Voorbraak, K.J.M. (2011) Crowdfunding for Financing New Ventures: Consequences of the Financial Model on Operational Decisions, Eindhoven, Eindhoven University of Technology.

Vukovic, M., Mariana, L. and Laredo, J. (2009) PeopleCloud for the Globally Integrated Enterprise, In Asit, D., Gittler, F. and Tourmani, F. (eds.), Service-Oriented Computing. Berlin: Springer Verlag, 109-114.

Wenzlaff, K., Gumpelmaier, W. and Eisfeld-Reschke, J. (2012) Definition von Crowdfunding, http://www.ikosom.de/2012/06/11/definitionvoncrowdfunding-beta/, accessed on 01.08.2014.

Wexler, M.N. (2011) 'Reconfiguring the sociology of the Crowd: exploring Crowdsourcing', International Journal of Sociology and Social Policy, Vol. 31, No. 1, pp.6-20.

Wheat, R.E., Wang, Y., Byrnes, J.E. and Ranganathan, J. (2013) 'Raising money for sctientific research through Crowdfunding', Trends in Ecology \& Evolution, Vol. 28, No. 2, pp.71-72.

Wiggins, A. and Crowston, K. (2011) 'From Conservation to Crowdsourcing: A Typology of Citizen Science', Proceedings of the 44th Hawai'i International Conference on System Science (HICSS-44), Vol. 2011, No. 44.

Wolf, M., Dirtheuer, K., Sagl, S. and Herrmann, G. (2012) Mobil - interaktiv - sozial: Der digitale Mensch von morgen „, always in touch“?, In Verclas, S. and Linnhoff-Popien, C. (eds.), Smart Mobile Apps. Berlin: Springer Verlag, 531-544.

Yang, J., Adamic, L.A. and Ackerman, M.S. (2008) Crowdsourcing and Knowledge Sharing: Strategic User Behavior on Taskcn. Paper presented at Proceedings of the 9th ACM Conference on Electronic Commerce, Chicago.

Zademach, H.-M. and Baumeister, C. (2013) Wagniskapital und Entrepreneurship: Grundlagen, empirische Befunde, Entwicklungstrends, In Pechlaner, H. and Doepfer, B.C. (eds.), Wertschöpfungskompetenz und Unternehmertum. Rahmenbedingungen für Entrepreneurship und Innovation in Regionen. Wiesbaden: Springer Gabler, 123-146.

Zhang, J. (2013) 'The wisdom of Crowdfunding', Communities and Banking, Vol. Winter, No. 2012, pp.30-31.

Zvilichovsky, D., Inbar, Y. and Barzilay, O. (2013) Playing Both Sides of the Market: Success and Reciprocity on Crowdfunding Platforms, SSRN Working Paper 2304101. 


\section{NOTES}

